Japan. Jour. Crop. Sci. 60 (1) : 146-152 (1991)

\title{
Changes in Activities and Levels of Pyruvate, Orthophosphate Dikinase with Induction of Crassulacean Acid Metabolism in Mesembryanthemum crystallinum L.*
}

\author{
Kazuyuki SaITOU, Yasunori NaKAMURA**, Yosinobu KaWAMITSU***, \\ Makoto MatsuOKA**, Muneaki SamejIMA** and Waichi Agata \\ (Department of Agriculture, Faculty of Agriculture, Kyushu University, Hakozaki, Fukuoka 812, Japan; \\ **National Institute of Agrobiological Resources, Tsukuba Science City, Tsukuba, Ibaraki 305, Japan) \\ Received July 30, 1990
}

\begin{abstract}
In Mesembryanthemum crystallinum $\mathrm{L}$. leaves exhibiting $\mathrm{C}_{3}$ photosynthesis, Crassulacean acid metabolism (CAM), as characterized by $\mathrm{CO}_{2}$ uptake during the dark period, was induced by exposing the plant roots to high $\mathrm{NaCl}$ concentration over a week. The increase in malate content in the leaves at the end of the dark period correlated with the increases in the activities of phosphoenolpyruvate carboxylase (PEPCase), NADP malic enzyme (NADP-ME) and pyruvate, orthophosphate dikinase (PPDK) which exhibited a maximum about a week after $\mathrm{NaCl}$ treatment. It was found that PPDK existed in $\mathrm{C}_{3}-M$. crystallinum and the increases in the activities of PEPCase and PPDK were accompanied by the de novo synthesis of these proteins.

Key words : Crassulacean acid metabolism induction, Mesembryanthemum crystallinum, Phosphoenolpyruvate carboxylase, Pyruvate, Orthophosphate dikinase.

Mesembryanthemum crystallinum L. の CAM 型光合成の誘導にともなうピルビン酸正リン酸ジキナー ゼの活性及びレベルの变化 : 斎藤和幸・中村保典 **・川満芳信***・松岡 信**・鮫島宗明**・縣 和一（九州 大学農学部・**農業生物資源研究所)

要 旨: $\mathrm{C}_{3}$ 型光合成を行っている Mesembryanthemum crystallinum L. の葉身は植物体の根を $\mathrm{NaCl}$ 処理 することによって処理後 1 週間で暗期に $\mathrm{CO}_{2}$ を吸収するようになり, 光合成型が $\mathrm{C}_{3}$ 型から Crassulacean acid metabolism (CAM) 型ヘシフトすることが認められた。葉身の暗期の終わりのリンゴ酸含量の増加の 推移はホスホエノールピルビン酸カルボキシラーゼ (PEPCase), NADP-リンゴ酸酵素 (NADP-ME) 及び ピルビン酸正リン酸ジキナーゼ (PPDK) 活性の増加の推移とほぼ一致しており, それらは $\mathrm{NaCl}$ 処理後約 1 週間で最大に達した。本研究では， $C_{3}$ 型 M. crystallinum の葉身にも PPDK が存在していることを見い 出し, CAM 型光合成へのシフトにともなう PEPCase 及び PPDK の活性の増加は, これらの醅素タンパ ク質の新たな合成によって達成されていることが明らかとなった。

キーワード:ベンケイソウ型酸代謝誘導, ピルビン酸正リン酸ジキナーゼ, ホスホエノールピルビン酸カルボ キシラーゼ, Mesembryanthemum crystallinum.
\end{abstract}

The halophilic species Mesembryanthemum crystallinum $\mathrm{L}$. shifts the photosynthetic $\mathrm{CO}_{2}$ fixation from $\mathrm{C}_{3}$ plant type to CAM plant type, which exhibits substantial $\mathrm{CO}_{2}$ uptake and malate synthesis in the dark by exposure to high salinity in the nutrient medium ${ }^{9,28)}$. The increases in the activities of phosphoenolpyruvate carboxylase (PEPCase) (EG 4.1.1.31) and other enzymes associated with CAM with high $\mathrm{NaCl}$ treatment have been documented $8,9,12,13,25)$. The increase in PEPCase activity is accounted for by an accumulation of the enzyme protein and

\footnotetext{
* The outline of this paper was presented at the $183 \mathrm{rd}$ meeting of the Crop Science Society of Japan, April, 1987. The present work was supported by a grant from the Ministry of Agriculture, Forestry and Fisheries.

*** Present address : College of Agriculture, University of the Ryukyus, Nishihara-cho, Okinawa 903-01, Japan.
}

mRNA $^{8,12,19,22,23)}$. However, little is known about whether pyruvate, orthophosphate dikinase (PPDK) (EC 2.7.9.1), which is one of the key enzymes of photosynthetic $\mathrm{CO}_{2}$ fixation in $\mathrm{C}_{4}$ plants $^{10)}$ and some CAM plants ${ }^{14)}$, is newly synthesized during the induction of CAM.

PPDK was thought to be absent from $\mathrm{C}_{3}$ plants ${ }^{7)}$ and was reported to be absent from $\mathrm{C}_{3}-M$. crystallinum ${ }^{13,27)}$. However, the presence of PPDK in leaves of some $\mathrm{C}_{3}$ plants $3,4,11,18$ ) and mRNA for PPDK in $\mathrm{C}_{3}-M$. crystallinum has been documented ${ }^{23)}$.

In this study, changes in activities and levels of PPDK during the induction of CAM in $M$. crystallinum were examined.

\section{Materials and Methods}

1. Plant materials Mesembryanthemum crystallinum L. was grown from seed (collected from 
a natural population at Guerrero Negro in Baja, California) in soil until plants were approximately 5 weeks of age and transferred in culture solution containing $3 \mathrm{mM} \mathrm{KNO}_{3}, 2$ $\mathrm{mM} \mathrm{Ca}\left(\mathrm{NO}_{3}\right)_{2}, 0.5 \mathrm{mM} \mathrm{MgSO}_{4}, 0.5 \mathrm{mM}$ $\mathrm{NH}_{4} \mathrm{H}_{2} \mathrm{PO}_{4}, 0.5 \mathrm{mM}\left(\mathrm{NH}_{4}\right)_{2} \mathrm{HPO}_{4}, 12.5 \mu \mathrm{M}$ $\mathrm{H}_{3} \mathrm{BO}_{4}, 1 \mu \mathrm{M} \mathrm{MnSO}_{4}, 1 \mu \mathrm{M} \mathrm{ZnSO}_{4}, 0.25$ $\mu \mathrm{M} \mathrm{CuSO}_{4}, 0.03 \mu \mathrm{M}\left(\mathrm{NH}_{4}\right)_{6} \mathrm{Mo}_{7} \mathrm{O}_{24}, 10 \mu \mathrm{M}$ Fe-EDTA. Five plants were grown in each pot which contained $4 \mathrm{~L}$ of culture solution. The culture solution was changed every seven days. All plants were maintained in a growth cabinet under a $12 \mathrm{hr}$ light $\left(20^{\circ} \mathrm{C}, 70 \%\right.$ relative humidity, 12,000 Lux) and $12 \mathrm{hr}$ dark $\left(15^{\circ} \mathrm{C}, 70 \%\right.$ relative humidity) cycle. When the plants became 4.3 leaf age, the $\mathrm{NaCl}$ concentration of the nutrient solution was brought to $400 \mathrm{mM} \mathrm{NaCl}$ by steps of $100 \mathrm{mM}$ every day.

2. $\mathrm{CO}_{2}$ exchange and transpiration measurements Rates of $\mathrm{CO}_{2}$ assimilation and water transpiration were simultaneously measured by using a climate-controlled chamber. Details of gas exchange system and methods have been described previously ${ }^{2)}$. Light was provided by metal-halide lamps (Toshiba, Modal D-400) filtered through approximately $15 \mathrm{~cm}$ of running water.

3. Extraction methods The third foliar leaves which fully expanded prior to increasing the $\mathrm{NaCl}$ concentration were used for the preparation of the enzyme extracts. The disks with a total area of $0.8 \mathrm{~cm}^{2}$ were excised from the leaves using a cork borer in the second half of the light period and ground with a teflon homogenizer in $650 \mu \mathrm{L}$ of ice-cold solution containing $150 \mathrm{mM}$ Tricine- $\mathrm{NaOH}(\mathrm{pH} \mathrm{8.1)}$, $5 \mathrm{mM}$ dithiothreitol (DTT), $10 \mathrm{mM} \mathrm{MgCl}_{2}, 1$ $\mathrm{mM}$ ethylenediaminetetraacetate $\left(\mathrm{Na}_{2}-\right.$ EDTA) and $0.5 \%(\mathrm{w} / \mathrm{v})$ polyvinylpyrrolidone (PVP). After centrifugation at $13,000 \mathrm{rpm}$ and $4^{\circ} \mathrm{C}$ for $1 \mathrm{~min}$, the supernatant was immediately used for enzyme assays.

When NAD malic enzyme (NAD-ME) (EC 1.1.1.38) was measured, non-centrifuged crude extracts were incubated with $0.5 \%$ triton X-100 for $5 \mathrm{~min}$ at room temperature. After centrifugation at $13,000 \mathrm{rpm}$ for $1 \mathrm{~min}$, the extracts were maintained at room temperature for $30 \mathrm{~min}$ prior to assay.

When PPDK was measured, the disks with a total leaf area of $0.8 \mathrm{~cm}^{2}$ were ground, after illumination, in $650 \mu \mathrm{L}$ of ice-cold solution containing $150 \mathrm{mM}$ Tricine- $\mathrm{NaOH}$ (pH 8.1), $2.5 \mathrm{mM}$ pyruvate, $5 \mathrm{mM}$ DTT, $1 \mathrm{mM} \mathrm{Na} \mathrm{m}_{2}-$ EDTA, $10 \mathrm{mM} \mathrm{MgCl}_{2}$ and $0.5 \%$ (w/v) PVP. After centrifugation at $13,000 \mathrm{rpm}$ for $1 \mathrm{~min}$ at room temperature, the supernatant was immediately used for enzyme assays and SDS gel electrophoresis.

4. Enzyme assays All enzymes were measured at $25^{\circ} \mathrm{C}$ by following the change in absorbance of $340 \mathrm{~nm}$ in a $1 \mathrm{~mL}$ reaction mixture as described below. The assay conditions for all enzymes tested were modified from the referred sources to give optimum activities in the extracts from $M$. crystallinum.

The assay mixture of ribulose-1,5bisphosphate carboxylase (RuBPCase) (EC 4.1.1.39) contained $100 \mathrm{mM}$ Hepes- $\mathrm{NaOH}$ (pH 8.0), $10 \mathrm{mM} \mathrm{KCl}, 1 \mathrm{mM} \mathrm{Na} \mathrm{N}_{2}$-EDTA, 30

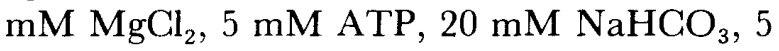
$\mathrm{mM}$ phosphocreatine, 13.5 IU phosphoglycerate kinase, 13.5 IU NAD glyceraldehyde-3phosphate dehydrogenase, 10 IU creatine phosphokinase, $0.2 \mathrm{mM}$ NADH, $1 \mathrm{mM}$ DTT and $20 \mu \mathrm{L}$ enzyme extract. The reaction was initiated by adding RuBP at a final concentration of $0.5 \mathrm{mM}^{24)}$.

The assay mixture of PEPCase contained 25 $\mathrm{mM}$ Bicine- $\mathrm{NaOH}$ ( $\mathrm{pH} 8.0$ ), $100 \mathrm{mM}$ Hepes$\mathrm{NaOH}$ (pH 8.0), $5 \mathrm{mM} \mathrm{MgCl}_{2}, 10 \mathrm{mM}$ $\mathrm{NaHCO}_{3}, 5 \mathrm{mM}$ DTT, $0.12 \mathrm{mM}$ NADH, 6 IU NAD malate dehydrogenase and $20 \mu \mathrm{L}$ enzyme extract. The reaction was initiated by adding PEP at a final concentration of 4 $\mathrm{mM}^{15)}$.

The assay mixture of NADP malic enzyme (NADP-ME) (EC 1.1.1.40) contained 100 mM Hepes- $\mathrm{NaOH}$ (pH 8.0), $5 \mathrm{mM} \mathrm{Na} \mathrm{Na}_{2}$ EDTA, $0.5 \mathrm{mM}$ NADP, $5 \mathrm{mM}$ malate, $5 \mathrm{mM}$ DTT and $25 \mu \mathrm{L}$ enzyme extract. The reaction was initiated by adding $\mathrm{MgCl}_{2}$ at a final concentration of $22.5 \mathrm{mM}^{24)}$.

The assay mixture of NAD-ME contained $100 \mathrm{mM}$ Hepes-HaOH (pH 7.4), $0.2 \mathrm{mM}$ $\mathrm{Na}_{2}$-EDTA, $2 \mathrm{mM}$ NAD, $5 \mathrm{mM}$ malate, $5 \mathrm{mM}$ DTT and $50 \mu \mathrm{L}$ enzyme extract. The reaction was initiated by adding $\mathrm{MnCl}_{2}$ at a final concentration of $5 \mathrm{mM}$ and coenzyme $\mathrm{A}$ at a final concentration of $75 \mu \mathrm{M}^{13)}$.

The assay mixture of PPDK contained 100 $\mathrm{mM}$ Tris-HCl $(\mathrm{pH} 8.0), 10 \mathrm{mM} \mathrm{MgCl}_{2}, 0.1$ $\mathrm{mM} \mathrm{Na}{ }_{2}$-EDTA, $1.25 \mathrm{mM}$ pyruvate, $2.5 \mathrm{mM}$ $\mathrm{K}_{2} \mathrm{HPO}_{4}, 0.2 \mathrm{mM} \mathrm{NADH}, 50 \mathrm{mM} \mathrm{NaHCO}$, 2 IU PEPCase, 2 IU NAD malate dehy- 
drogenase, $5 \mathrm{mM}$ DTT and $100 \mu \mathrm{L}$ enzyme extract. The reaction was initiated by adding ATP at a final concentration of $1.25 \mathrm{mM}^{21)}$.

5. Soluble protein and chlorophyll content The soluble protein content of the extracts was estimated by the method of Lowry et al. ${ }^{17)}$ after precipitating protein with $10 \%(\mathrm{w} / \mathrm{v})$ trichloroacetic acid. Bovine serum albumin was used as the reference protein. Chlorophyll was extracted with $80 \%$ acetone, and assayed according to Arnon ${ }^{5)}$.

6. Malate content Leaf disks were harvested from third foliar leaves at the end of the dark period. Malate was measured according to Möllering ${ }^{20)}$.

7. SDS gel electrophoresis (SDS-PAGE) and immunoblot analysis The samples were prepared for SDS-PAGE by mixing a three-fold volume of the protein solutions with SDS sample buffer and boiling immediately for $3 \mathrm{~min}$. Proteins were resolved by SDS-PAGE using a discontinuous buffer system ${ }^{16}$. Proteins were transferred electrophoretically onto nitrocellulose membranes using a semidry blotter (Saltorius, West Germany). The nitrocellulose membranes were incubated $30 \mathrm{~min}$ at room temperature in $20 \mathrm{mM}$ Tris- $\mathrm{HCl}(\mathrm{pH} \mathrm{7.4)}, 0$. $5 \mathrm{mM} \mathrm{NaCl}$ (TBS) containing $3 \%(\mathrm{w} / \mathrm{v})$ gelatin. Antibodies raised against maize leaf PEPCase and PPDK used in this report were the generous gift of Professor T. Sugiyama of Nagoya University. Immunoblots were carried out by incubating the nitrocellulose membranes overnight at room temperature in TBS containing $1 \%(\mathrm{w} / \mathrm{v})$ gelatin, $0.01 \%$ thimerosal and either anti-PEPCase or anti-PPDK antibody. The nitrocellulose membranes were washed in TBS containing $0.05 \%$ Tween 20 $(3 \times 10 \mathrm{~min})$ and incubated with horse-radish peroxidase-conjugated goat anti-(rabbit) IgG antibodies (Bio-Rad) for $1 \mathrm{hr}$ at room temperature. The nitrocellulose membranes were then washed in TBS containing $0.05 \%$ Tween $20(3 \times 10 \mathrm{~min})$ and rinsed in distilled water. The protein-antibody complexes were visualized using a solution containing 3,3'diaminobenzidine and cobalt ${ }^{1)}$.

\section{Results}

Diurnal change of the $\mathrm{CO}_{2}$ exchange rate were measured during the induction of CAM after $\mathrm{NaCl}$ treatment (Fig. $1 \mathrm{~A}$ ). The net $\mathrm{CO}_{2}$ exchange rate before $\mathrm{NaCl}$ treatment was almost constant in the light and dark periods. On the second day after $\mathrm{NaCl}$ treatment, the net $\mathrm{CO}_{2}$ uptake in the light period, especially around noon, decreased, while the net $\mathrm{CO}_{2}$ release in the dark period was constant. On the fourth day, the net $\mathrm{CO}_{2}$ uptake in the light period decreased to half of that before $\mathrm{NaCl}$ treatment. It was also noticed that the net $\mathrm{CO}_{2}$ release in the dark period (at about $21 \mathrm{~h}$ ) decreased remarkably. After a week, the net $\mathrm{CO}_{2}$ exchange rate showed a typical pattern of CAM, that is, a drastic depression of net $\mathrm{CO}_{2}$ uptake in the light and an appearance of that in the dark.

The leaf conductance in the light period decreased rapidly after $\mathrm{NaCl}$ treatment (Fig. $1 \mathrm{~B})$. Changes in leaf conductance in the light period were similar to those in the net $\mathrm{CO}_{2}$ exchange rate during the induction of CAM.

The activities of five major photosynthetic enzymes changed with increasing $\mathrm{NaCl}$ concentration in the nutrient solution (Figs. 2 and 3). The activities of RuBPCase, PEPCase, NADP-ME, NAD-ME and PPDK, which were extracted from the leaves of the nontreated plant on the fifteenth day, did not show any change from those before $\mathrm{NaCl}$ treatment. The RuBPCase activity before $\mathrm{NaCl}$ treatment was eight-fold that of the PEPGase activity. When the $\mathrm{NaCl}$ concentration increased to $400 \mathrm{mM}$, the activity of RuBPCase per unit of leaf area decreased gradually to half of the original level on the sixteenth day. On the other hand, the activity of PEPCase continued to increase remarkably until the sixth day and it remained constant thereafter. As a consequence, the PEPCase activity in the treated plant was thirteen-fold that in the non-treated plant on the sixteenth day. Hence, it was higher than RuBPCase activity. The NADP-ME activity was similarly enhanced by the $\mathrm{NaCl}$ treatment to approximately three-fold that of the non-treated plant. By contrast, the NAD-ME activity of the treated plant was slightly higher than that of the non-treated plant on the sixteenth day.

The PPDK activity in $\mathrm{C}_{3}-M$. crystallinum was very low, but it was enhanced by the $\mathrm{NaCl}$ treatment on the fifteenth day to approximately five-fold that of the non-treated plant (Fig. 3).

Accumulation of malate in the leaves increased at the end of the dark period by the 


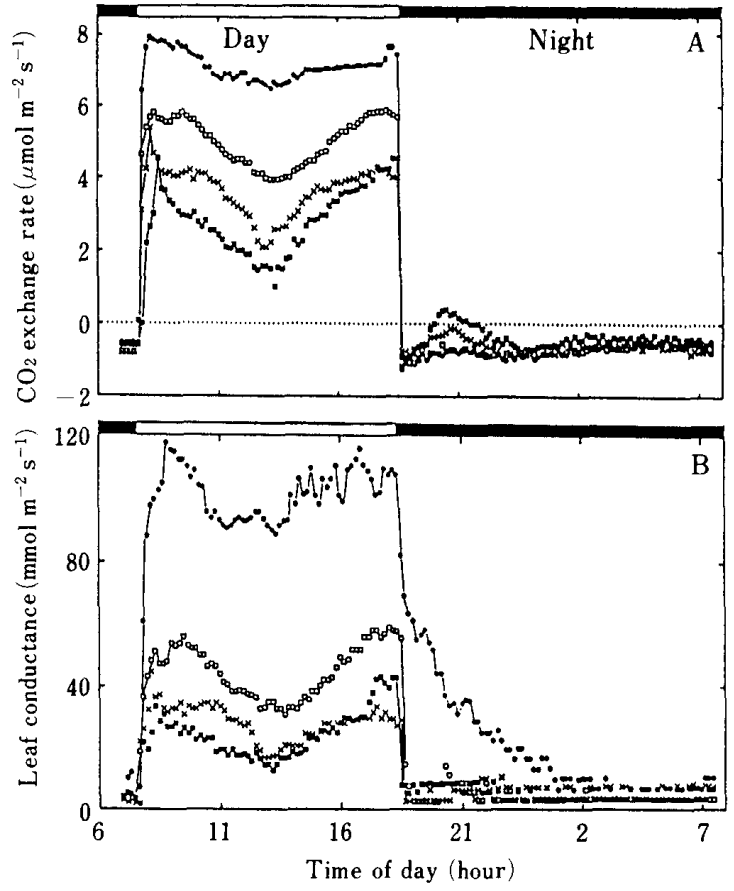

Fig. 1. Diurnal patterns of the $\mathrm{CO}_{2}$ exchange rate (A) and the leaf conductance (B) in $M$. crystallinum during the induction of CAM with adding $\mathrm{NaCl}$ in the culture solution. $\bullet$, Before $\mathrm{NaCl}$ treatment; $O$, on the second day after $\mathrm{NaCl}$ treatment ; $\times$, on the fourth day; $\boldsymbol{a}$, on the seventh day.

high $\mathrm{NaCl}$ treatment, and it became fifty-three fold as compared with that before the $\mathrm{NaCl}$ treatment on the ninth day (Fig. 3). There was a close relationship between accumulation of malate at the end of the dark period and the activity of PEPCase. This result was similar to that observed in the earlier experiments $\mathrm{s}^{9,13,25)}$.

The activities of PEPCase and PPDK in the extracts from the leaves of the non-treated plant $\left(\mathrm{C}_{3}-M\right.$. crystallinum $)$ and the treated plant on the ninth day (CAM- M. crystallinum) were expressed per unit of leaf area, on a chlorophyll basis and on a protein basis in Table 1 . The increase in the enzyme activities with the $\mathrm{NaCl}$ treatment was independent of the basis.

The extracts from the leaves of the nontreated plant $\left(\mathrm{C}_{3}-M\right.$. crystallinum $)$ and the treated plant on the ninth day (CAM- $M$. crystallinum), having the same leaf area, were subjected to SDS-PAGE and analyzed by the anti-PEPCase antibody and the anti-PPDK antibody (Fig. 4). The intensity of staining increased in several regions of the gel. When

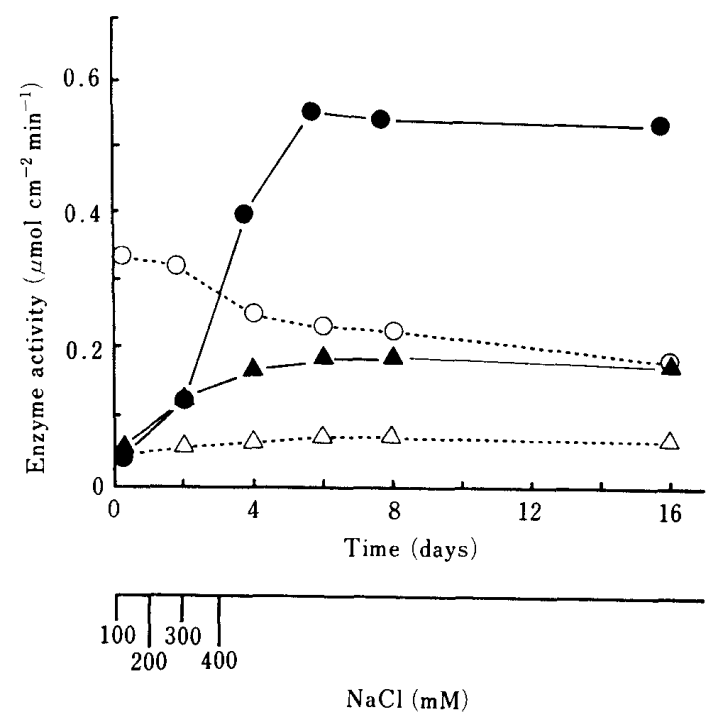

Fig. 2. Changes in the activity of PEPCase, RuBPCase, NADP-ME and NAD-ME with adding $\mathrm{NaCl}$ in the culture solution. $\bullet$, PEPCase ; $\bigcirc$, RuBPCase ; $\Delta$, NADP$\mathrm{ME} ; \triangle$, NAD-ME.

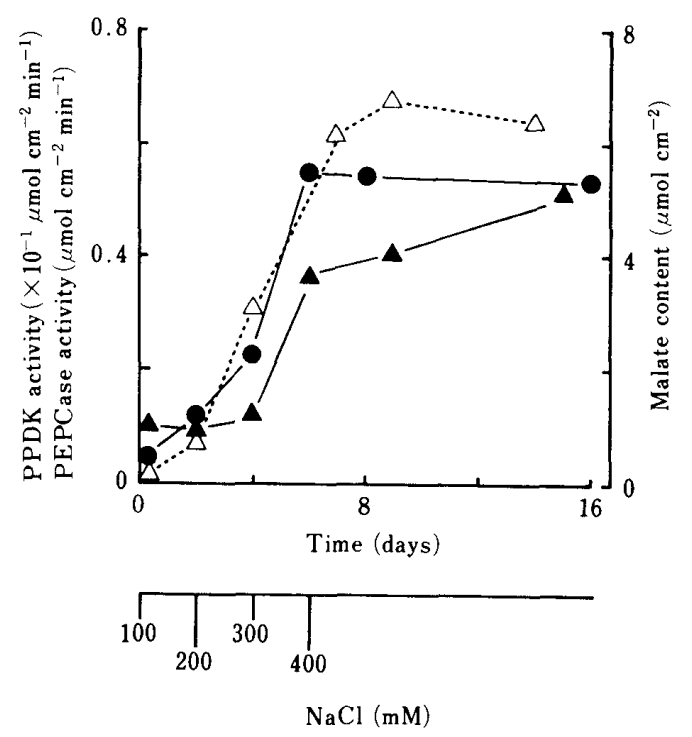

Fig. 3. Changes in the activity of PEPCase and PPDK and the content of malate at the end of the dark period with adding $\mathrm{NaCl}$ in the culture solution. O, PEPCase ; $\triangle, \operatorname{PPDK} ; \triangle$, malate.

the bands obtained from CAM- $M$. crystallinum were compared with corresponding bands from $\mathrm{C}_{3}-M$. crystallinum, remarkable increases in the quantity of the polypeptides denoted by the band numbers 1 to 4 appeared on the Coomassie-stained gel.

In the extracts from the leaves of both $\mathrm{C}_{3}$ and CAM- $M$. crystallinum, the bands denoted by the numbers 1 (ca. $114 \mathrm{kD}$ ) and 2 (ca. 106 
$\mathrm{kD})$ reacted with the anti-PEPCase antibody (Fig. $4 \mathrm{~B}$ ). The intensity of the bands increased with the $\mathrm{NaCl}$ treatment. The increase in PEPCase activity was accompanied by the increase in PEPGase protein.

In $\mathrm{C}_{3}-M$. crystallinum, an immunoreactive protein with the anti-PPDK antibody was detected as a faint band and had a molecular weight of about $98 \mathrm{kD}$ (Fig. $4 \mathrm{C}$ ). The intensity of the PPDK band increased with the $\mathrm{NaCl}$ treatment. The increase in PPDK activity was also accompanied by the increase in PPDK protein.

The amount of soluble protein per unit of leaf area increased until the second day after $\mathrm{NaCl}$ treatment and it remained constant thereafter (Fig. 5). Fluctuation of the chlorophyll content with the $\mathrm{NaCl}$ treatment was small.

\section{Discussion}

The pattern of net $\mathrm{CO}_{2}$ exchange rate indicated a typical feature of CAM with a remarkable depression of net $\mathrm{CO}_{2}$ uptake during the light period and an appearance of that in the dark period at a week after $\mathrm{NaCl}$ treatment (Fig. 1). Accumulation of malate at the end of the dark period reached a maximum about a week after $\mathrm{NaCl}$ treatment (Fig. $3)$. The activities of PEPCase, NADP-ME and PPDK, which were active in CAM photosynthesis, also reached a maximum about a weeek after $\mathrm{NaCl}$ treatment (Figs. 2 and 3). These results indicated that the induction of CAM in $M$. crystallinum was caused by the increase in the activity of CAM photosynthesis.

Whether the increase in the activities of CAM photosynthetic enzymes are caused by activation of existing enzyme proteins or by synthesis of new enzyme proteins is important in relation to cellular control of the enzymes and the development of CAM.

As the activities of PEPCase and PPDK which were key enzymes in CAM photosynthesis increased remarkably with the $\mathrm{NaCl}$ treatment, the levels of these enzyme proteins were studied by immunological analysis of proteins from crude extracts (Fig. 4). The two bands denoted by the numbers 1 and 2 reacted with the anti-PEPCase antibody in $\mathrm{C}_{3}$ - or CAM- $M$. crystallinum. In leaves of CAM- $M$. crystallinum, the band denoted by the number 2 was stained more intensely than that denot-
Table 1. PEPCase and PPDK activities in the leaves of $\mathrm{C}_{3}$ - and CAM- $M$. crystallinum.

\begin{tabular}{lll}
\hline Enzyme & $\mathrm{C}_{3}$ & $\mathrm{CAM}^{*}$ \\
\hline PEP carboxylase & & \\
$\left(\mu \mathrm{mol} \mathrm{min}^{-1} \mathrm{~cm}^{-1}\right)$ & 0.05 & 0.61 \\
$\left(\mu \mathrm{mol} \mathrm{min}^{-1} \mathrm{mg}^{-1}\right.$ chlorophyll $)$ & 0.69 & 8.03 \\
$\left(\mu \mathrm{mol} \mathrm{min} \mathrm{mg}^{-1}\right.$ protein $)$ & 0.06 & 0.50 \\
& & \\
PPDK & & \\
$\left(\mu \mathrm{mol} \mathrm{min}-1 \mathrm{~cm}^{-1}\right)$ & 0.01 & 0.04 \\
$\left(\mu \mathrm{mol} \mathrm{min}^{-1} \mathrm{mg}^{-1}\right.$ chlorophyll $)$ & 0.17 & 0.50 \\
$\left(\mu \mathrm{mol} \mathrm{min} \mathrm{mg}^{-1} \mathrm{mg}^{-1}\right.$ protein $)$ & 0.01 & 0.03 \\
\hline
\end{tabular}

${ }^{*}:$ The treated plant on the ninth day after $\mathrm{NaCl}$ treatment.

ed by the number 1 . The PEPCase bands was stained more intensely in the extract from CAM- $M$. crystallinum than that from $\mathrm{C}_{3}-M$. crystallinum. This result indicated that the increase in the activity of PEPCase in $M$. crystallinum was accompanied by the increase in PEPGase protein.

The band denoted by the number 3 in $\mathrm{G}_{3}$ or CAM- $M$. crystallinum reacted with the anti-PPDK antibody (Fig. 4). The PPDK band was stained more intensely in the extract from CAM- M. crystallinum than that from $\mathrm{C}_{3}$ $M$. crystallinum. This result indicated that the increase in the activity of PPDK in $M$. crystallinum was accompanied by the increase in PPDK protein.

PPDK was reported to be absent from $\mathrm{C}_{3}$ $M$. crystallinum $^{13,27)}$. However, the presence of mRNA of PPDK in $\mathrm{C}_{3}-M$. crystallinum was reported ${ }^{23)}$. We were able to measure low PPDK activity in the extracts from $\mathrm{C}_{3}-M$. crystallinum (Table 1) and to detect a faint PPDK protein by immunoblot analysis (Fig. $4 \mathrm{C}$ ). Therefore, we could show the enzymes required for $\mathrm{C}_{4}$ acid metabolism were present in $\mathrm{C}_{3}-M$. crystallinum, although the amount was much less.

Aoyagi and Bassham ${ }^{4}$ proposed that $\mathrm{C}_{4}$ intracellular carbon transport was concerned with photosynthesis. If the $\mathrm{C}_{4}$ intracellular carbon transport is present, PEPCase must be active during the light period in $\mathrm{C}_{3}-M$. crystallinum. In CAM plants, PEPCase is inactive during the day time, but active at night ${ }^{26)}$. Cushman et al. ${ }^{6)}$ reported that two distinct 

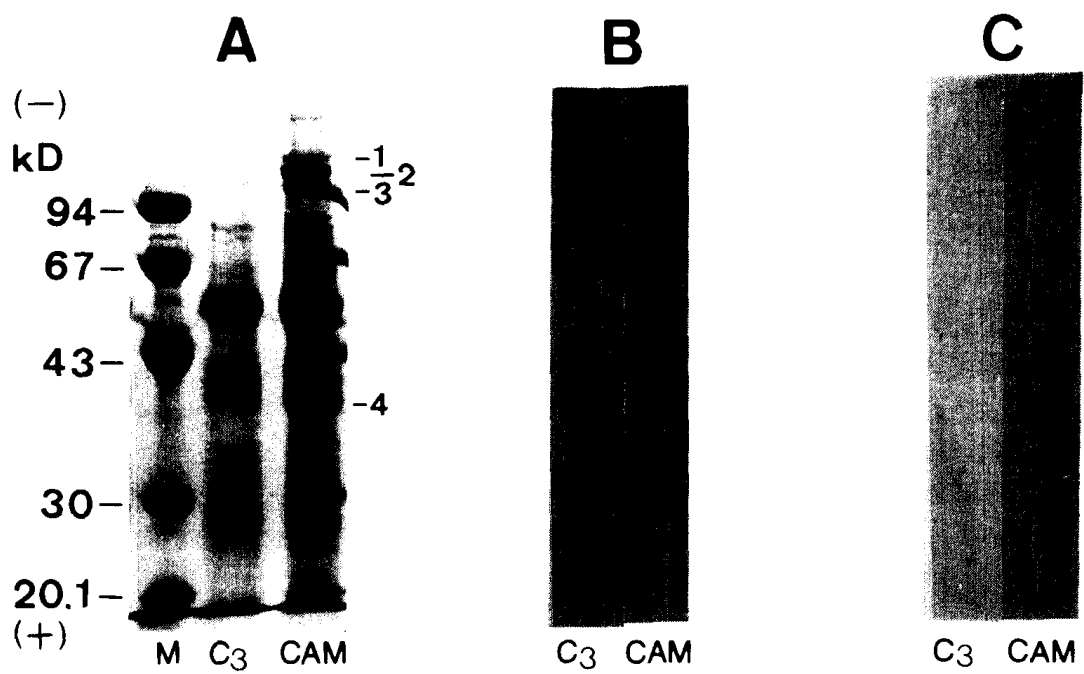

Fig. 4. Coomassie-stained SDS polyacrylamide slab gel (A), immunoblot analysis with anti-PEPCase antibody (B) and with anti-PPDK antibody $(C)$ in the extracts from the leaves of the non-treated plant $\left(\mathrm{C}_{3}\right)$ and the treated plant with $400 \mathrm{mM} \mathrm{NaCl}$ on the ninth day (CAM). The extracts had the same leaf area. Protein contents were $10 \mu \mathrm{g}$ for the non-treated plant and $14 \mu \mathrm{g}$ for the treated plant. $M$, mass markers.

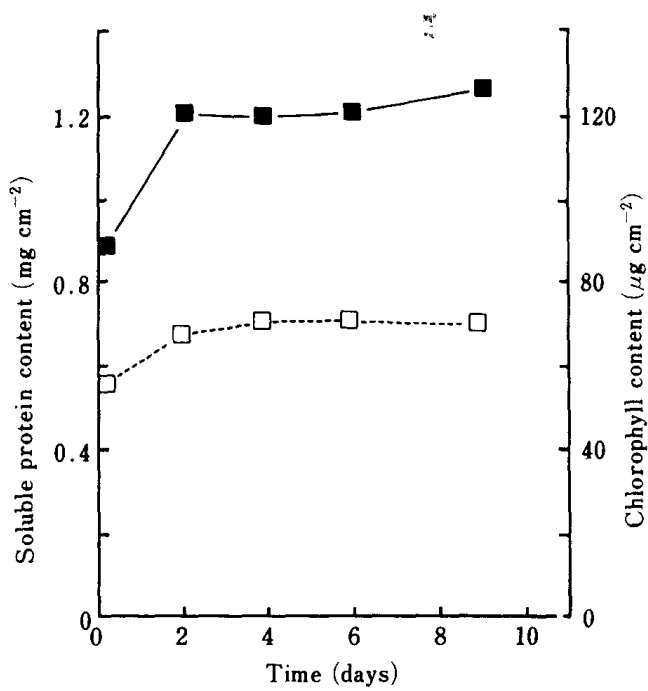

Fig. 5. Changes in soluble protein and chlorophyll content in the leaves of $M$. crystallinum. a, Soluble protein ; $\square$, chlorophyll.

genomic PEPCase genes that differ markedly in their expression during GAM induction were present in $M$. crystallinum. Therefore, it will be interesting to see whether the different regulation of PEPCase is present between in the different PEPCase isoforms or not. Knowledge of the properties of PEPCase isoforms in $M$. crystallinum could help in planning future plant breeding or even molecular genetic engineering designed to impart CAM characteristics to $\mathrm{C}_{3}$ plants.

\section{Acknowledgment}

We thank Professor T. Sugiyama of Nagoya Univ. for his gifts of anti-PEPCase and antiPPDK antibodies.

\section{References}

1. Adams, J.C. 1981. Heavy metal intensification of DAB-based HRP reaction product. J. Histol. Cytochem. $29: 775$.

2. Agata, W., Y. Kawamitsu, S. Hakoyama and Y. Shima 1986. A system for measuring leaf gas exchange based on regulating vapour pressure difference. Photosynthesis Res. 9 : 345-357.

3. Aoyagi, K. and J.A. Bassham 1984. Pyruvate orthophosphate dikinase of $\mathrm{C}_{3}$ seeds and leaves as compared to the enzyme from maize. Plant. Physiol. 75 : 387-392.

4. — 1986. Appearance and accumulation of $\mathrm{C}_{4}$ carbon pathway enzymes in developing wheat leaves. Plant Physiol. $80: 334$ -340 .

5. Arnon, D.I. 1949. Copper enzymes in isolated chloroplasts. Polyphenoloxydase in Beta vulgaris. Plant Physiol. $24: 1-15$.

6. Cushman, J.C., G. Meyer, C.B. Michalowski, J.M. Schmitt and H.J. Bohnert 1989. Salt stress leads to differential expression of two isogenes of phosphoenolpyruvate carboxylase during Cras- 
sulacean acid metabolism induction in the common ice plant. The Plant Cell 1:715-725.

7. Edwards, G.E., M.S.B. Ku and M. D. Hatch 1982. Photosynthesis in Panicum milioides, a species with reduced photorespiration. Plant Cell Physiol. $23: 1185-1195$.

8. Foster, J.G., G.E. Edwards and K. Winter 1982. Changes in levels of phosphoenolpyruvate carboxylase with induction of Crassulacean acid metabolism in Mesembryanthemum crystallinum L. Plant Cell Physiol. 23 : 585-594.

9. Greenway, H., K. Winter and G. Lüttge 1978. Phosphoenolpyruvate carboxylase during development of Crassulacean acid metabolism and during a diurnal cycle in Mesembryanthemum crystallinum. J. Exp. Bot. 29 : 547-559.

10. Hatch, M.D. and C.R. Slack 1968. A new enzyme for the interconversion of pyruvate and phosphoenolpyruvate and its role in the $\mathrm{C}_{4}$ dicarboxylic acid pathway of photosynthesis. Biochem. J. $106: 141-146$.

11. Hata, S. and M. Matsuoka 1987. Immunological studies on pyruvate orthophosphate dikinase in $\mathrm{C}_{3}$ plants. Plant Cell physiol. $28: 635-641$.

12. Höfner, R., L. Vazqvez-Moreno, K. Winter, H.J. Bohnert and J.M. Schmitt 1987. Induction of Crassulacean acid metabolism in Mesembryanthemum crystallinum by high salinity: Mass increase and de novo synthesis of PEP-carboxylase. Plant Physiol. 83 : 915-919.

13. Holtum, J.A. and K. Winter 1982. Activity of enzymes of carbon metabolism during the induction of Crassulacean acid metabolism in Mesembryanthemum crystallinum. Planta $155: 8-16$.

14. Kluge, M. and C.B. Osmond 1971 Pyruvate Pi dikinase in Crassulacean acid metabolism. Naturwissenshaften $58: 414-415$.

15. - 1972. Studies on phosphoenolpyruvate carboxylase and other enzymes of Crassulacean acid metabolism of Bryophyllum tubiflorum and Sedum prealtum. Z. Pflanzenphysiol. $66: 97-105$.

16. Laemmlie, U.K. 1970. Cleavage of structural proteins during the assembly of the head of bacteriophage T4. Nature $227: 680-685$.

17. Lowry, O.H., N.J. Rosebrough, A.L. Farr and R. J. Randall 1951. Protein determination with the Folin phenol reagent. J. Biol. Chem. 193: 265 -275 .

18. Meyer, A.O., G.J. Kelly and E. Latzko 1982. Pyruvate orthophosphate dikinase from the immature grains of cereal grasses. Plant Physiol. 69 :
$7-10$.

19. Michalowski, G.B., S.W. Olson, M. Piepenbrock, J.M. Schmitt and H.J. Bohnert 1989. Time course of mRNA induction elicited by salt stress in the common ice plant (Mesembryanthemum crystallinum). Plant Physiol. $89: 811-816$.

20. Möllering, H. 1974. Determination with malate dehydrogenase and glutamate-oxaloacetate transaminase. In Methods of Enzymatic Analysis (Ed.) H.U. Bergmeyer, Academic Press, New York. 1589-1593.

21. Nakamoto, H. and G.E. Edwards 1983. Influence of oxygen and temperature on the dark inactivation of pyruvate, orthophosphate dikinase and NADP-malate dehydrogenase in maize. Plant Physiol. $71: 568-573$.

22. Ostrem, J.A., S.W. Olson, J.M. Schmitt and H.J. Bohnert 1987. Salt stress increases the level of translatable mRNA for phosphoenolpyruvate carboxylase in Mesembryanthemum crystallinum. Plant Physiol. 84 : 1270-1275.

23. Schmitt, J.M., C.B. Michalowski and H.J. Bohnert 1988. Gene expression during CAM induction under salt stress in Mesembryanthemum: CDNA library and increased levels of mRNA for phosphoenolpyruvate carboxylase and pyruvate orthophosphate dikinase. Photosynth. Res. 17:159 -171 .

24. Usuda, H. 1984. Variations in the photosynthesis rate and activity of photosynthetic enzymes in maize leaf tissue of different ages. Plant Cell Physiol. 25 : 1297-1301.

25. Winter, K. 1979. Effect of different $\mathrm{CO}_{2}$ regimes on the induction of Crassulacean acid metabolism in Mesembryanthemum crystallinum L. Aust. J. Plant Physiol. 6 : 589-594.

26. - 1982. Properties of phosphoenolpyruvate carboxylase in rapidly prepared, desalted leaf extracts of the Crassulacean acid metabolism plant Mesembryanthemum crystallinum L. Planta 154:298-308.

27. —, J.G. Foster, G.E. Edwards and J.A.M. Holtum 1982. Intracellular localization of enzymes of carbon metabolism in Mesembryanthemum crystallinum exhibiting $\mathrm{C}_{3}$ photosynthetic characteristics or performing Crassulacean acid metabolism. Plant Physiol. 69 : 300-307.

28. — and D.J. von Willert 1972. NaClinduzierter Crassulacean-Säuerestoffwechsel bei Mesembryanthemum crystallinum. Z. Pflanzenphysiol. $67: 166-170$. 